\title{
GROWTH IN LARVAL AND METAMORPHOSED EURYPHARYNX PELECANOIDES VAILLANT, 1882 (PISCES, ANGUILLIFORMES, EURYPHARYNGIDAE) FROM THE MID NORTH ATLANTIC*
}

\author{
by \\ W. L. VAN UTRECHT \\ Institute of Taxonomic Zoology (Zoölogisch Museum), University of Amsterdam, \\ P.O. Box 4766, 1009 AT Amsterdam, The Netherlands
}

\begin{abstract}
The difference between the larvae of Eurypharynx pelecanoides and Saccopharynx ampullaceus, both belonging to the suborder Saccopharyngoidei (formerly Lyomeri), does not consist only of different numbers in myomeres but also of the structure of the suspensorium of the lower jaw. In $E$. pelecanoides it consists of two separate bones, the hyomandibulare and the quadratum. According to Orton (1963) in $S$. ampullaceus the suspensorium consists of only one piece of bone.

In the larvae of $E$. pelecanoides there is no upper jaw or related structure present, up to a length of about $20 \mathrm{~mm}$. In the larvae as well as in the metamorphosed specimens of $E$. pelecanoides, growth in length of the bony components of the skull, forming the upper and lower jaw and its suspensorium, is strong and significant in caudal direction. There is also a small but significant increase in length of the part of the skull between the eyes and the tip of the snout.
\end{abstract}

\section{RÉSUMÉ}

La différence entre les larves d'Eurypharynx pelecanoides et de Saccopharynx ampullaceus, les deux appartenant au sousordre Saccopharyngoidei (auparavant Lyomeri), consiste non seulement en un nombre différent de myomères, mais aussi en une structure différente du suspensorium de la mâchoire inférieure: chez $E$. pelecanoides celle-ci est représentée par deux os (hyomandibulare et quadratum), tandis que (d'après Orton, 1963) le suspensorium de $S$. ampullaceus est représenté par un os unique.

Les larves d' $E$. pelecanoides jusqu'à une longueur de 20 mm environ, ne présentent pas de mâchoire supérieure ou de structure apparentée à celle-ci. Chez larves et exemplaires métamorphosés de cette espèce, la croissance en longueur des composants osseux du crâne formant les mâchoires supérieure et inférieure ainsi que le suspenso-

- Amsterdam Mid North Atlantic Plankton Expedition (AMNAPE), Project 101A, Report no. 34, supported by a grant of the Netherlands Ministry of Education and Sciences. Report no. 33 has been published in Bijdragen tot de Dierkunde, 57 (2): 164-182 (1987). rium de cette dernière, est forte et significative en direction caudale. On remarque aussi une augmentation légère mais significative de la longueur de la partie du crâne comprise entre les yeux et l'extrémité du museau.

\section{INTRODUCTION}

Bertin $(1936,1937,1938)$ gave detailed descriptions of "Leptocephalus latissimus" Schmidt, 1912, already mentioned by Schmidt (1909) and of "Leptocephalus pseudolatissimus" Bertin, 1934. He supposed a relation of the " $L$. pseudolatissimus" larva with Eurypharynx pelecanoides Vaillant, 1882. "Leptocephalus latissimus" is characterized by a large number of myomeres, varying between 240 and 250, of which 38-43 are preanal, whereas ' $L$. pseudolatissimus" has a smaller number of myomeres, varying between 115 and 125, of which 34-41 preanal.

Orton (1963) concluded that " $L$. pseudolatissimus" is most probably the larva of $E$. pelecanoides. This is mainly based on the fact that both Eurypharynx and this larva have five gill arches and five slits, while she mentioned that Saccopharynx Mitchill, 1824 and its larva $L$. latissimus both have four gill arches and slits. She also gave a reinterpretation of the anatomical features of the head of this larva. In the present paper the terminology used by Orton is followed.

Smith (1979) stated that the larval stage of Saccopharynx is L. latissimus, whereas that of Eurypharynx is L. pseudolatissimus.

Castle (1983) mentioned L. latissimus as the larva of Saccopharynx ampullaceus Harwood, 1827 , with a minimum of 138 and a maximum of 250 myomeres, while $L$. pseudolatissimus, the 
larva of $E$. pelecanoides, has a minimum of 97 and a maximum of 125 myomeres.

Gartner (1983) described sexual dimorphism in $E$. pelecanoides. He found greatly enlarged olfactory organs in the males of this species. In the samples that were available and described below, this was not found, as the animals were most probably still sexually immature.

The aim of the present study is to analyse the growth of the head and its respective components in the larvae and metamorphosed specimens of $E$. pelecanoides.

\section{MATERIAL AND METHODS}

The specimens of $E$. pelecanoides used in the present study were caught with an acoustically controlled combined Rectangular Midwater Trawl (RMT 1+8) with opening and closing device (Baker et al., 1973). Sampling was done during the Amsterdam Mid North Atlantic Plankton Expeditions, between latitudes $55^{\circ}$ and $25^{\circ} \mathrm{N}$ along approximately $30^{\circ} \mathrm{W}$ longitude. The successive AMNAPE expeditions, made with the research vessel H.M.S. "Tydeman", were held in 1980 (11 April-2 May), 1981 (15 September-6 October), 1982 (1 February27 February) and in 1983 (27 May-24 June). In each season the sampling stations were as much as possible at the same positions (fig. 1). Measurements of depth and speed of the net and of the water temperature were recorded by a net monitor. For details about positions and hydrographic conditions see Van der Spoel $(1981,1985)$ and Van der Spoel \& Meerdink (1983).

The larvae of $E$. pelecanoides in the samples were fixed and preserved in $70 \%$ alcohol, whereas the metamorphosed specimens were fixed in $4 \%$ formalin for a short time and then also preserved in $70 \%$ alcohol.

\section{RESULTS AND DISCUSSION}

From the present samples (table I) it is evident that no larvae are caught in summer and very few in spring. In autumn (1981) 20 larvae were caught, and 8 during the winter of 1982 . These larvae were caught between $42^{\circ}$ and $29^{\circ} \mathrm{N}$, mainly south of $40^{\circ} \mathrm{N}$, at depths from 40 to 500 $\mathrm{m}$ (see table I). This is in accordance with Bertin's observations (1938). The metamorphosed $E$. pelecanoides were not encountered during winter. In the other seasons most metamorphosed larvae were caught south of $40^{\circ} \mathrm{N}$ (only two specimens at about $52^{\circ}$ and $54^{\circ} \mathrm{N}$ ). All

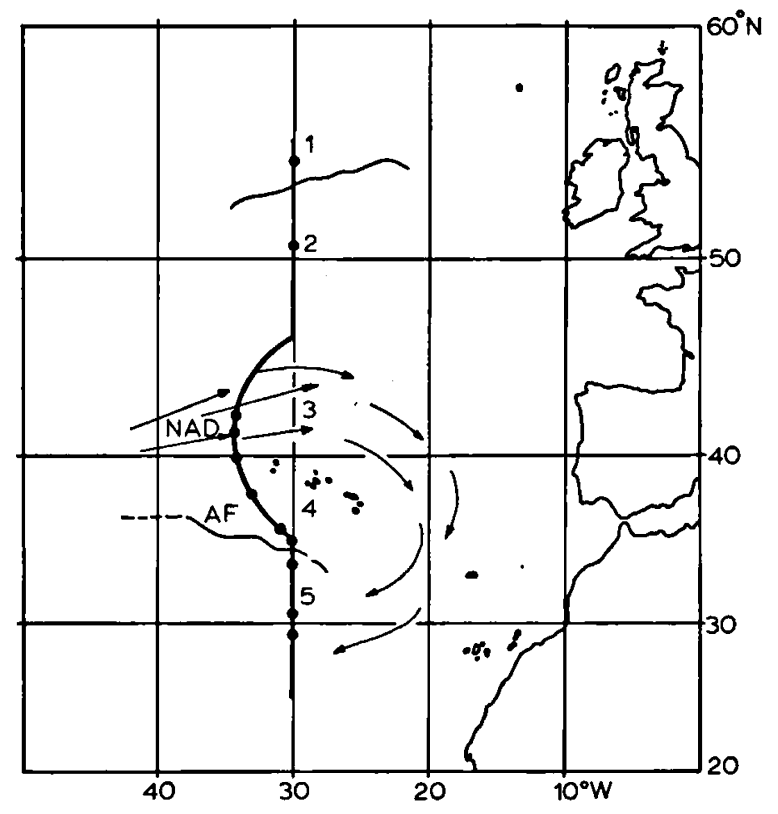

Fig. 1. Transect fished during AMNAPE 1980-1983. The dots indicate the stations where Eurypharynx pelecanoides or its larvae were caught: 1 , subarctic waters; 2 , temperate waters; 3, transitional zone; 4, gyral waters; 5, subtropical waters; $\mathrm{AF}=$ Azores Front; NAD $=$ North Atlantic Drift (after Pafort-Van Iersel, 1985).

these specimens were caught well below $400 \mathrm{~m}$ (see table I).

The larvae of $E$. pelecanoides were often caught together with the larvae of Cyema atrum Günther, 1878 (Anguilliformes, Cyematidae); adults of $C$. atrum were never caught, indicating that these are living at a deeper level than $E$. pelecanoides.

Both $E$. pelecanoides and $S$. ampullaceus belong to the suborder Saccopharyngoidei (formerly Lyomeri, cf. Böhlke (1966) and Nelson (1984: 112)). Larvae of Saccopharyngoidei pass through a rather typical eel-like stage, with deep, laterally compressed, relatively short, leaf-like and transparent bodies. Their snout is very short, their head narrow. Bertin (1938) described and depicted $L$. pseudolatissimus, and gave also a short description of $L$. latissimus. He has drawn the head of a larva of $20 \mathrm{~mm}$ length (his fig. 14) with a maxillary bone on which a series of teeth is attached. Orton (1963) mentioned a total length for $L$. pseudolatissimus of 35 $\mathrm{mm}$ (incl. metamorphosing specimens). In her 
TABLe I

Morphometric and station data.

\begin{tabular}{|c|c|c|c|c|c|c|c|c|c|c|}
\hline \multirow[t]{2}{*}{ Sta. } & \multirow[t]{2}{*}{ Haul } & \multirow[t]{2}{*}{ Position } & \multirow[t]{2}{*}{ Date } & \multirow[t]{2}{*}{$\begin{array}{l}D(\text { ay) } \\
N(\text { ight })\end{array}$} & \multirow[t]{2}{*}{$\begin{array}{l}\text { Depth } \\
\text { in } \mathrm{m}\end{array}$} & \multirow{2}{*}{$\begin{array}{l}\text { Temp. } \\
\text { depth } \\
\left({ }^{\circ} \mathrm{C}\right)\end{array}$} & \multicolumn{2}{|c|}{$\begin{array}{l}\text { Leptocephalus } \\
\text { pseudolatissimus }\end{array}$} & \multicolumn{2}{|l|}{$\begin{array}{l}\text { Eurypharynx } \\
\text { pelecanoides }\end{array}$} \\
\hline & & & & & & & $\begin{array}{l}\text { Number of } \\
\text { specimens }\end{array}$ & $\begin{array}{l}\text { Length } \\
\text { in } \mathrm{mm}\end{array}$ & $\begin{array}{l}\text { Number of } \\
\text { specimens }\end{array}$ & $\begin{array}{l}\text { Length } \\
\text { in } \mathrm{mm}\end{array}$ \\
\hline 18 & 1 & $\begin{array}{l}39^{\circ} 58.5^{\prime} \mathrm{N} \\
36^{\circ} 24.9^{\prime} \mathrm{W}\end{array}$ & 22-IV-'80 & $\mathrm{N}$ & $520-1130$ & $9.50^{\circ}$ & & & 2 & $\begin{array}{l}183 \\
270\end{array}$ \\
\hline 18 & 10 & $\begin{array}{l}39^{\circ} 53.9^{\prime} \mathrm{N} \\
35^{\circ} 58.9^{\prime} \mathrm{W}\end{array}$ & 22-IV-' 80 & D & $440-910$ & $10.40^{\circ}$ & & & 1 & 247 \\
\hline 20 & 1 & $\begin{array}{l}35^{\circ} 27.2^{\prime} \mathrm{N} \\
31^{\circ} 51.6^{\prime} \mathrm{W}\end{array}$ & 25-IV-' 80 & D & $505-870$ & $10.50^{\circ}$ & & & 1 & 39.3 \\
\hline 20 & 3 & $\begin{array}{l}35^{\circ} 22.7^{\prime} \mathrm{N} \\
31^{\circ} 44.9^{\prime} \mathrm{W}\end{array}$ & 25-IV-'80 & D & $770-1250$ & $8.25^{\circ}$ & & & 1 & 115.4 \\
\hline 21 & 6 & $\begin{array}{l}33^{\circ} 40.5^{\prime} \mathrm{N} \\
30^{\circ} 40.6^{\prime} \mathrm{W}\end{array}$ & 27-IV-'80 & $\mathbf{N}$ & $510-1000$ & $10.60^{\circ}$ & & & 3 & $\begin{array}{l}75.2 \\
137 \\
141.8\end{array}$ \\
\hline 22 & 1 & $\begin{array}{l}32^{\circ} 19.0^{\prime} \mathrm{N} \\
30^{\circ} 03.1^{\prime} \mathrm{W}\end{array}$ & 27-IV-' 80 & D & $500-1000$ & $10.50^{\circ}$ & & & 2 & $\begin{array}{c}87 \\
138.5\end{array}$ \\
\hline 22 & 7 & $\begin{array}{l}31^{\circ} 58.2^{\prime} \mathrm{N} \\
29^{\circ} 54.0^{\prime} \mathrm{W}\end{array}$ & 28-IV-'80 & $\mathbf{N}$ & $90-200$ & $17.85^{\circ}$ & 1 & 23.6 & & \\
\hline 23 & 2 & $\begin{array}{l}30^{\circ} 39.9^{\prime} \mathrm{N} \\
29^{\circ} 59.5^{\prime} \mathrm{W}\end{array}$ & 28-IV-'80 & D & $505-960$ & $11.00^{\circ}$ & & & 1 & 69.2 \\
\hline 25 & 1 & $\begin{array}{l}28^{\circ} 42.0^{\prime} \mathrm{N} \\
29^{\circ} 59.1^{\prime} \mathrm{W}\end{array}$ & 29-IV-'80 & $\mathrm{D}$ & $\begin{array}{c}490-1000 \\
\therefore\end{array}$ & $10.50^{\circ}$ & & & 6 & $\begin{array}{c}306.2 \\
217 \\
119 \\
95 \\
127.3 \\
98.5\end{array}$ \\
\hline 37 & 9 & $\begin{array}{l}52^{\circ} 58.5^{\prime} \mathrm{N} \\
29^{\circ} 37.4^{\prime} \mathrm{W}\end{array}$ & $7-X-' 81$ & $\mathrm{D}$ & $400-1000$ & $4.15^{\circ}$ & & & 1 & 303 \\
\hline 42 & 10 & $\begin{array}{l}41^{\circ} 48.3^{\prime} \mathrm{N} \\
34^{\circ} 23.2^{\prime} \mathrm{W}\end{array}$ & 30-IX-'81 & $\mathrm{D}$ & $45-80$ & $16.80^{\circ}$ & 1 & 16.0 & & \\
\hline 47 & 6 & $\begin{array}{l}35^{\circ} 07.6^{\prime} \mathrm{N} \\
31^{\circ} 22.7^{\prime} \mathrm{W}\end{array}$ & 23-IX-'81 & $\mathbf{N}$ & $50-105$ & $19.35^{\circ}$ & 3 & $\begin{array}{l}22.3 \\
34.3 \\
15.4\end{array}$ & & \\
\hline 47 & 7 & $\begin{array}{l}35^{\circ} 07.1^{\prime} \mathrm{N} \\
31^{\circ} 19.5^{\prime} \mathrm{W}\end{array}$ & 24-IX-'81 & $\mathbf{N}$ & $95-190$ & $16.25^{\circ}$ & 3 & $\begin{array}{l}28.6 \\
26.7 \\
29.0\end{array}$ & & . \\
\hline 48 & 8 & $\begin{array}{l}34^{\circ} 12.9^{\prime} \mathrm{N} \\
31^{\circ} 11.9^{\prime} \mathrm{W}\end{array}$ & 23-IX-'81 & $\mathbf{N}$ & $500-1150$ & $9.90^{\circ}$ & 1 & 30.0 & 3 & $\begin{array}{r}91 \\
103 \\
97\end{array}$ \\
\hline 48 & 13 & $\begin{array}{l}34^{\circ} 11.4^{\prime} \mathrm{N} \\
31^{\circ} 11.3^{\prime} \mathrm{W}\end{array}$ & 23-IX-'81 & $\mathrm{D}$ & $60-100$ & $18.70^{\circ}$ & 1 & 25.2 & & \\
\hline 49 & 6 & $\begin{array}{l}31^{\circ} 44.5^{\prime} \mathrm{N} \\
20^{\circ} 35.3^{\prime} \mathrm{W}\end{array}$ & 21-IX-'81 & $\mathbf{N}$ & $45-107$ & $19.80^{\circ}$ & 6 & $\begin{array}{l}16.2 \\
26.9 \\
31.2 \\
22.5 \\
29.9 \\
31.0\end{array}$ & & \\
\hline 49 & 8 & $\begin{array}{l}31^{\circ} 45.6^{\prime} \mathrm{N} \\
29^{\circ} 32.9^{\prime} \mathrm{W}\end{array}$ & 22-IX-'81 & $\mathbf{N}$ & $105-230$ & $17.45^{\circ}$ & 5 & $\begin{array}{l}24.7 \\
26.3 \\
28.5 \\
27.3 \\
19.2\end{array}$ & & \\
\hline
\end{tabular}


TABLE I (continuation)

\begin{tabular}{|c|c|c|c|c|c|c|c|c|c|c|}
\hline \multirow[t]{2}{*}{ Sta. } & \multirow[t]{2}{*}{ Haul } & \multirow[t]{2}{*}{ Position } & \multirow[t]{2}{*}{ Date } & \multirow[t]{2}{*}{$\begin{array}{l}D \text { (ay) } \\
N \text { (ight) }\end{array}$} & \multirow[t]{2}{*}{$\begin{array}{l}\text { Depth } \\
\text { in } \mathrm{m}\end{array}$} & \multirow{2}{*}{$\begin{array}{l}\text { Temp. } \\
\text { depth } \\
\left({ }^{\circ} \mathrm{C}\right)\end{array}$} & \multicolumn{2}{|c|}{$\begin{array}{l}\text { Leptocephalus } \\
\text { pseudolatissimus }\end{array}$} & \multicolumn{2}{|l|}{$\begin{array}{l}\text { Eurypharynx } \\
\text { pelecanoides }\end{array}$} \\
\hline & & & & & & & $\begin{array}{l}\text { Number of } \\
\text { specimens }\end{array}$ & $\begin{array}{l}\text { Length } \\
\text { in } \mathrm{mm}\end{array}$ & $\begin{array}{l}\text { Number of } \\
\text { specimens }\end{array}$ & $\begin{array}{l}\text { Length } \\
\text { in } \mathrm{mm}\end{array}$ \\
\hline 51 & 12 & $\begin{array}{l}28^{\circ} 07.0^{\prime} \mathrm{N} \\
29^{\circ} 52.8^{\prime} \mathrm{W}\end{array}$ & 19-IX-'81 & $\mathbf{N}$ & $500-1050$ & $10.45^{\circ}$ & & & 5 & $\begin{array}{r}145.5 \\
106.2 \\
126.2 \\
99.2 \\
-\end{array}$ \\
\hline 55 & 4 & $\begin{array}{l}27^{\circ} 02.5^{\prime} \mathrm{N} \\
20^{\circ} 17.7^{\prime} \mathrm{W}\end{array}$ & 15-IX-'81 & D & $570-1000$ & $9.15^{\circ}$ & & & 1 & 370 \\
\hline 62 & 45 & $\begin{array}{l}40^{\circ} 56.5^{\prime} \mathrm{N} \\
35^{\circ} 40.0^{\prime} \mathrm{W}\end{array}$ & 14-II' 82 & $\mathbf{N}$ & 195-305 & $15.30^{\circ}$ & 2 & $\begin{array}{l}30 \\
32\end{array}$ & & \\
\hline 63 & 14 & $\begin{array}{l}39^{\circ} 43.0^{\prime} \mathrm{N} \\
35^{\circ} 48.9^{\prime} \mathrm{W}\end{array}$ & 15-II-'82 & $\mathrm{D} / \mathrm{N}$ & $100-200$ & $15.25^{\circ}$ & 1 & 32.5 & & \\
\hline 63 & 15 & $\begin{array}{l}39^{\circ} 40.1^{\prime} \mathrm{N} \\
35^{\circ} 44.6^{\prime} \mathrm{W}\end{array}$ & 15-II-' 82 & $\mathbf{N}$ & $40-100$ & $15.30^{\circ}$ & 1 & 26.3 & & \\
\hline 65 & 20 & $\begin{array}{l}29^{\circ} 59.4^{\prime} \mathrm{N} \\
29^{\circ} 34.8^{\prime} \mathrm{W}\end{array}$ & 19-II-'82 & $\mathbf{N}$ & $490-1000$ & $10.30^{\circ}$ & 1 & 9.6 & & \\
\hline 66 & 8 & $\begin{array}{l}30^{\circ} 02.1^{\prime} \mathrm{N} \\
29^{\circ} 13.1^{\prime} \mathrm{W}\end{array}$ & 20-II-'82 & D & $100-200$ & $18.10^{\circ}$ & 1 & 12.9 & & \\
\hline 68 & 5 & $\begin{array}{l}30^{\circ} 02.6^{\prime} \mathrm{N} \\
28^{\circ} 03.0^{\prime} \mathrm{W}\end{array}$ & 21-II-'82 & $\mathbf{N}$ & $80-190$ & $18.55^{\circ}$ & 2 & $\begin{array}{l}21.4 \\
23.0\end{array}$ & & \\
\hline 74 & 10 & $\begin{array}{l}54^{\circ} 20.9^{\prime} \mathrm{N} \\
29^{\circ} 53.7^{\prime} \mathrm{W}\end{array}$ & 19-VI-'83 & $\mathbf{N}$ & $1000-1750$ & $3.45^{\circ}$ & & & 1 & 150 \\
\hline 81 & 6 & $\begin{array}{l}40^{\circ} 56.2^{\prime} \mathrm{N} \\
35^{\circ} 31.6^{\prime} \mathrm{W}\end{array}$ & 11-VI-'83 & $\mathrm{D} / \mathrm{N}$ & $500-1000$ & $8.75^{\circ}$ & & & 1 & 352 \\
\hline 81 & 17 & $\begin{array}{l}40^{\circ} 58.5^{\prime} \mathrm{N} \\
35^{\circ} 27.5^{\prime} \mathrm{W}\end{array}$ & 12-VI-'83 & N/D & $505-1000$ & $8.55^{\circ}$ & & & 3 & $\begin{array}{l}215 \\
231 \\
160\end{array}$ \\
\hline 84 & 37 & $\begin{array}{l}35^{\circ} 11.8^{\prime} \mathrm{N} \\
31^{\circ} 31.4^{\prime} \mathrm{W}\end{array}$ & 6-VI-'83 & N/D & $500-1000$ & $9.95^{\circ}$ & & & 1. & 126 \\
\hline
\end{tabular}

material the greatest length of the larvae is $\mathbf{3 4 . 3}$ $\mathrm{mm}$.

The components of the skull of the larva of $E$. pelecanoides are shown in fig. 2 and are comparable to those in the larva of $S$. ampullaceus (see Orton, 1963, figs. 1 and 2). In a $19 \mathrm{~mm}$ larva of $E$. pelecanoides (fig. 2a) the following skeletal cartilaginous parts are visible: brain case and snout, hyomandibulare, quadratum, cartilago Meckeli, ceratohyale, interhyale and operculare. Furthermore, there is a thin sheet of tissue stretched between the tip of the snout and the articulation between quadratum and cartilago Meckeli. At its rim a number of teeth is attached. In a $34.4 \mathrm{~mm}$, older larva (fig. 2b) a thin cartilaginous rod, supporting the rim of the sheet of tissue, is present between the tip of the snout and the quadratum.

Orton (1963) pointed to the strong development and nearly vertical position of the suspensorium, by which the lower jaw is attached to the skull. In the larvae of $E$. pelecanoides this suspensorium, composed of a hyomandibulare and a quadratum, are clearly separate bones (see Bertin, 1938, fig. 14 and present paper, figs. $2 a$ and $b$ ). This is in contrast with the situation in the larvae of $S$. ampullaceus, for which Orton (1963) points to the fact that the 

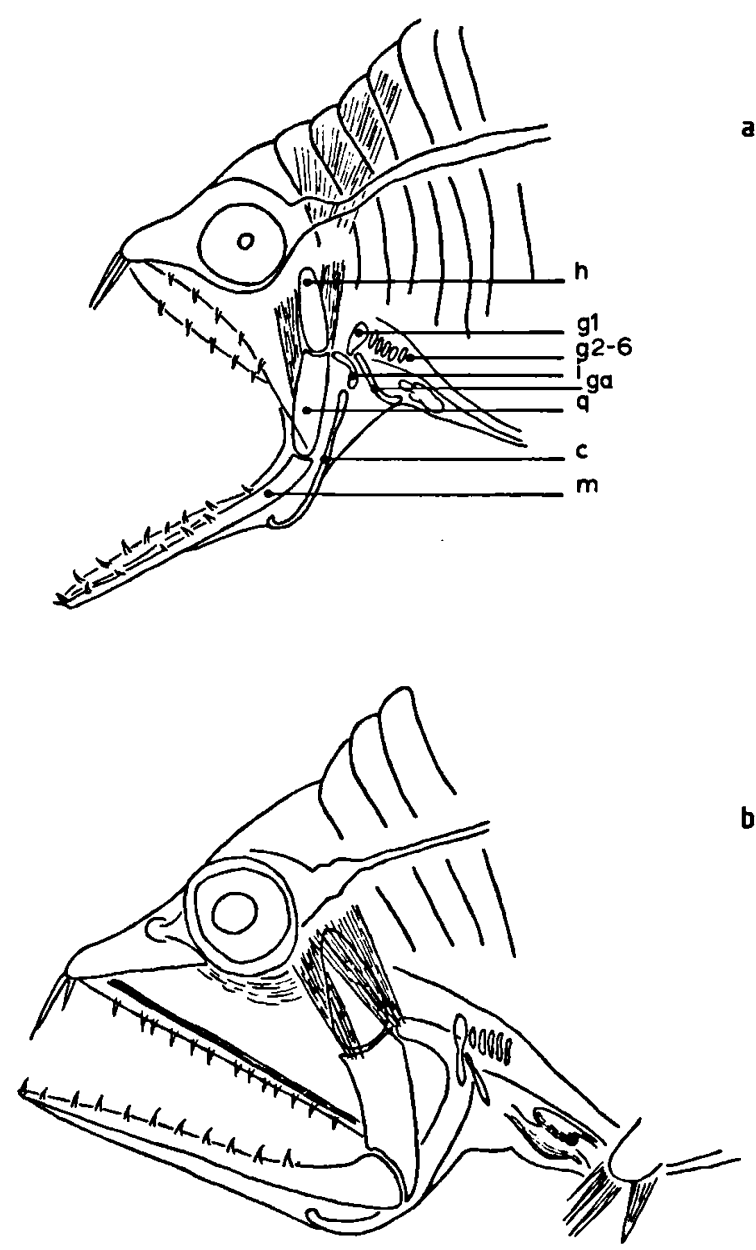

Fig. 2. a, Head of a larva of Eurypharynx pelecanoides, 13.5 $\mathrm{mm}$ in length: $\mathrm{c}=$ ceratohyale; $\mathrm{g} 1=$ first gill slit; $\mathrm{g} 2-6$ = second to sixth gill slit; $\mathrm{ga}=$ gill $\mathrm{arch} ; \mathrm{h}=$ hyomandibulare; $\mathrm{i}=$ interhyale; $\mathbf{m}=$ cartilago Meckeli; $\quad$ q = quadratum.

b, Head of a larva of $E$. pelecanoides, $34.4 \mathrm{~mm}$ in length.

two parts are united and form one piece of bone.

So the larvae of these two species are not only merely characterized by the total number of myomeres, but also by a difference in the structure of the suspensorium.

A striking difference exists between the smaller larvae (up to a length of about $20 \mathrm{~mm}$ TL) in the present samples, in which no maxillary bone could be seen, and those described earlier for $E$. pelecanoides (cf. Bertin, 1938) and S. ampullaceus (cf. Bertin, 1936). A maxillary bone is depicted by Bertin (1938) in his fig. 14 of a $20 \mathrm{~mm}$ larva and in $E$. pelecanoides, and by Orton (1963) in her figs. 1 and 2 of a $16 \mathrm{~mm}$ larva of $S$. ampullaceus.

From the present samples serial microscopic sections of the heads of larvae of $E$. pelecanoides of increasing length (TL: $15.4 \mathrm{~mm} ; 22.3 \mathrm{~mm}$; $34.3 \mathrm{~mm}$ ) have been made. In the smaller larvae a more or less triangular thin sheet of tissue, without traces of cellular cartilage, is present. This is stretched between the tip of the snout and the angle of the gape, formed by the articulation of the cartilago Meckeli and the quadratum. Dorsally it is attached to the base of the skull and the snout (fig. 2a). At its lower rim a few small denticles are attached, and this situation remains up to a length of about 20 $\mathrm{mm}$. In the head of a specimen of about $34 \mathrm{~mm}$ in length, a fine rod of cellular cartilage is developing in the lower rim of the sheet of tissue, which then also becomes slightly thickened (fig. 2b).

For the larva of $S$. ampullaceus the presence of the maxillary bone might be explained as a special character in this species, just as the fusion of the quadratum with the hyomandibulare (Orton, 1963). As only one small metamorphosed specimen of $S$. ampullaceus was available in the present sample, this could not be examined.

The larvae of $E$. pelecanoides studied by Bertin (1938) and those used for the present study fall both in the range of variation given by Castle (1983) with respect to their numbers of myomeres. As their general appearance and morphological details also agree, it can be safely concluded that in both cases larvae of $E$. pelecanoides are concerned. This makes the difference between the smaller larvae as described by Bertin (1938) and those in the present series remarkable.

The homology of the single long bone in the upper jaw of the larger larvae and metamorphosed specimens seemed to be settled by Tchernavin (1947), who found that the lower end of it is connected with the inner surface of the quadratum, mediad to the adductor muscles. It should therefore occupy the mor- 


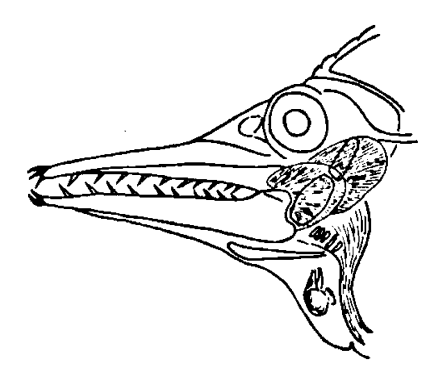

Fig. 3. Head of a larva of Cyema atrum, $21.4 \mathrm{~mm}$ in length.

phological position of a palatopterygoid element, rather than that of the maxillary bone. It is, however, remarkable that a part of the bones of the skull, the palatinal complex, in E.pelecanoides seems to come relatively late into development. This strongly contrasts with the situation as found in $S$. ampullaceus by Orton (1963). This may raise questions about the taxonomic position of both Eurypharynx and Saccopharynx within the suborder Saccopharyngoidei. As a very basic feature is concerned the two genera may belong to separate families of different origin.

Orton (1963) compared the anatomical features in the heads of the two species mentioned above, with those of Cyema atrum. This larva has the same general appearance; it has also a deep, laterally compressed body and head. She states that also in the larvae of this species the "jaw suspensorium is directed backward rather than forward as it is in many other eels". This could not be confirmed in series of larvae of $C$. atrum, available from the mid North Atlantic. Instead, the suspensorium is in a nearly vertical position and slightly directed forward. It is attached to the skull in a position at the posterior side of the eye as it is in the larvae of Eurypharynx and Saccopharynx. Moreover, the snout is in this species well developed and long, and all skeletal components of the skull are present and consist of cellular cartilage (fig. 3).

Raju (1974) compared the leptocephali of the order Saccopharyngiformes with those of Cyema, giving similarities of the larvae. They have short deep bodies, V-shaped myotomes, and elongated suspensorium. He attributes the differences in the adults to changes undergone during metamorphosis. However, the presence of maxillary bones and the short nearly vertical suspensorium in Cyema are not mentioned.

From 25 larvae varying in length from 9.6 to $34.3 \mathrm{~mm}$, and from 29 metamorphosed


Fig. 4. Growth of the skeletal components of the head of the larva of Eurypharynx pelecanoides: $a=$ cartilago Meckeli; $\mathrm{b}=$ quadratum; $\mathrm{c}=$ "upper jaw"; $d=$ snout; $e=$ hyomandibulare. 


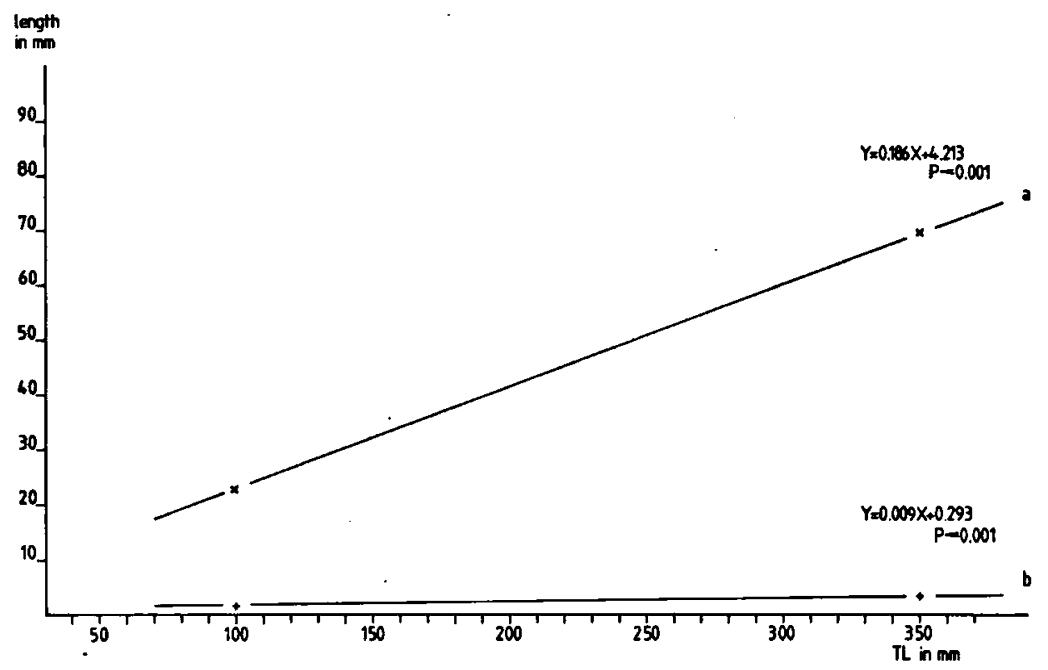

Fig. 5. Growth of skeletal components of the head of metamorphosed specimens of Eurypharynx pelecanoides: $a=$ "upper jaw"; $b=$ snout.

specimens of $E$. pelecanoides, varying in length from 39.9 to $370 \mathrm{~mm}$, a series of measurements has been taken.

In the larvae the preanal length is used as percentage of the total length. Regression analysis shows that there is no significant change in the relative position of the anus. The calculated regression line is nearly horizontal. The length of the following parts and bones in the head of the larvae were measured: cartilago Meckeli, quadratum, "upper jaw" (distance between tip of snout to angle of gape), snout (distance between tip of snout and centre of eye), and the hyomandibular bone.

As is shown in fig. 4 all these parts show a significant increase in length with increasing length of the animals. The increase in length of the hyomandibular bone and the quadratum is relatively small, as is the increase in length of the snout. A strong increase in length is found in the cartilago Meckeli and the part ultimately forming the "upper jaw". This shows a growth in the head in caudal direction.

This process continues in the metamorphosed specimens (fig. 5), whereas hardly any increase occurs in the distance between the tip of the snout and the centre of the eye, which even strengthens the suggestion for growth in caudal direction.

\section{REFERENCES}

Baker, A. de C., M. R. Clarke \& M. J. Harris, 1973. The N.I.O. combination net (RMT 1+8) and further developments of rectangular midwater trawls. J. mar. biol. Ass. U.K., 53: 167-184, pls. I-II.

Bertin, L., 1934. Les poissons apodes appartenant au sous-ordre des Lyomères. Dana Rep., 3: 1-56.

- - 1936. Sur une série de Leptocéphales appartenant au genre Saccopharynx Mitchill. C.r. hebd. Séanc. Acad. Sci., Paris, 203: 1540-1542.

- - 1937. Les poissons abyssaux du genre Cyema Günther (anatomie, embryologie, bionomie). Dana Rep., 10: 1-30.

-, 1938. Formes nouvelles et formes larvaires de poissons apodes appartenant au sous-ordre Lyomères. Dana Rep., 15: 1-26.

Böнlke, J. E., 1966. Order Lyomeri. Deep-sea Gulpers. In: Mem. Sears Fdn. mar. Res., 1. Fishes of the Western North Atlantic, 5. Order Iniomi, Order Lyomeri: 603-628.

Castle, P. H. J., 1983. Notacanthiformes and Anguilliformes: Development. In: Ontogeny and systematics of fishes. Spec. Publ. Amer. Soc. Ichthyol. Herpetol., 1: 62-93.

Gartner, J. V., 1983. Sexual dimorphism in the bathypelagic Gulper Eel Eurypharynx pelecanoides (Lyomeri: Eurypharyngidae), with comments on reproductive strategy. Copeia, 1983 (2): 560-563.

Nelson, J. S., 1984. Fishes of the world (2nd ed.): i-xv, 1-523 (John Wiley \& Sons, New York etc.).

Orton, G. L., 1963. Notes on the larval anatomy of fishes of the order Lyomeri. Copeia, 1963 (1): 6-15.

Pafort-van Iersel, T. 1985. Contributions to pelagic zoogeography of the mid North Atlantic Ocean, 2. 
Faunal patterns and boundaries between $25^{\circ} \mathrm{N}$ and $55^{\circ} \mathrm{N}$. Plankton News-Letter Rep. Ser., Amsterdam, 2: 1-35.

Raju, S. N., 1974. Three new species of the genus Monognathus and the leptocephali of the order Saccopharyngiformes. Fish. Bull., 72 (2): 547-562.

SснміDт, J., 1909. On the occurrence of leptocephali (lar$\mathrm{val}$ muraenoids) in the Atlantic W. of Europe. Meddr. Kommn. Havunders., (Fisk.) 3 (6): 1-19, 2 pls., 1 chart.

Smith, D. G., 1979. Guide to the leptocephali (Elopiformes, Anguilliformes, Notacanthiformes). NOAA tech. Rep., NMFS Circ., 424: 1-39.

SPOEL, S. VAN DER, 1981. List of discrete depth samples and open net hauls of the Amsterdam Mid North
Atlantic Plankton Expedition 1980 (project 101A). Bull. zoöl. Mus. Univ. Amsterdam, 8 (1): 1-10.

hauls of the Amsterdam Mid North Atlantic Plankton Expeditions 1982 and 1983 (Project 101A). Bull. zoöl. Mus. Univ. Amsterdam, 10 (17): 129-152.

Spoel, S. van der \& A. G. H. A. Meerding, 1983. List of discrete depth samples and open net hauls of the Amsterdam Mid North Atlantic Plankton Expedition 1981 (Project 101A). Bull. zoöl. Mus. Univ. Amsterdam, 9 (9): 78-91.

Tchernavin, V. V., 1947. Six specimens of Lyomeri in the British Museum (with notes on the skeleton of Lyomeri). J. Linn. Soc. (Zool.), 41 (279): 287-350, pls. 2-3. 